\title{
The Study Role of Demographic Characteristics In The Attachment level of Users of Urban Spaces, Case Study: Imam Street of Mahabad City in Iran
}

\author{
Hassan Houshyar*, Dalir Alavi** \\ *Assistant Professor of geography and Urban Planning Payame Noor University in Iran \\ **Lecturer Department of Mathematics University of Payame Noor
}

\begin{abstract}
Socio-demographic features have been reported as an important factor in human attachment to places in several studies. So, regarding the role of public spaces on human social life, this study tries to examine this effect in a certain case in Iran regarding some socio-demographic indicators like: gender, age, education, marriage statue and job. With this aim, we surveyed place attachment in one of the most important public spaces in Mahabad, based on four its dimensions: functional, emotional, behavioral and cognitive attachment. Therefore, significance of the correlations between those socio-demographic indicators and different aspects of place attachment was evaluated. The interviews carried out with 598 of Mahabad citizens that participated in this study by random selection. We analyze the result with SPSS software applying T-test, Pearson correlation and F-test (ANOVA) exams. The results indicate, in comparison with other examined indicators; only user's education level had significant relation with the place attachment degree and its emotional dimension. In addition, singles, older participants and also labors group reported more behavioral attachment to the place.
\end{abstract}

Keywords: Attachment to place, education, Gender, marital status and occupation.

\section{INTRODUCTION}

Relationship between man and space is one of the most important research topics in the field of Architecture \& Urban Planning and attachment to place, one of the most-discussed issues in the field. In various studies has been done so far on this have been several variables. That a significant proportion of its are noted individual features. As far have been individual characteristics social and cultural human subjects of research in the field of science, psychology, sociology, urban geography and urban planning. But of what, adds the importance of research the study is the type of place. Therefore, given the importance of urban spaces, the collective life of citizens and the necessity establish a link between men and place him again; this study was conducted in urban public spaces.

\section{Research questions}

1 - Is there a significant relationship between demographic characteristics and level of attachment to place it?

2 - What is there the dimension of attachment to place under the influence of demographic variables?

\section{Literature Review}

Research done in the field of human relations and locations dating back mainly in the area of psychology, to the 1960s and 1970s, Means when was emphasized importance of place and its role in health increasingly. In this context came various terms such as sense of place, place identity, attachment to place and phrases from this. Among these attachment to place is as the main study, emotional expression a special place (Hidalgo \& Hernandez, 2001; Moore \& Graefe, 1994; Williams et al., 1992). He relies on cognition and emotion (Low \& Altman, 1992; Proshansky et al 1983). In general can be said attachment to place, based process that is rooted in human interaction is based on a person's emotions and how to understanding and respond to the place where he needs (Daneshpour, 2010). This means that is the method of evaluation and judgment of the individual location based on their needs, causing to the location and shape of frequent positive emotions within him, be it a product, a person's behavior is influenced by the location.

Studies in this area have so far on the various factors that can be achieved in the three categories:

- Studies that pointed to the location features (Stedman, 2003; Eisenhauer et al, 2000; Bonaiuto et al, 2002).

- Studies that have looked time of factors (Low \& Altman, 1992; Bonaiuto et al, 1999; Rohe \& Stegman, 1994).

- Studies that rely on features of human (Rubinstein \& Parmelee, 1992; Riley, 1992; Ellaway \& Macintyre, 1997; Low \& McDonough, 2001; Pretty et al, 2003). 
Those studies have emphasized the characteristics of individual user's show that is different the attachment location from person to person (Riley, 1992 and Tuan, 1977). They choose Based on the deliberate preference, which is the characteristic of the person, and the places to be interested to it. Researchers have shown that forming individuals' attachments to places affected by the individual characteristics of users (Johnson 1998; Williams et al. 1992) and is social knowledge, beliefs and attitudes individuals (Ahrentzen, 1992). The explanation characteristics of the individual and their role in the interactions with location has been mentioned of various factors such as location, age, gender, income, marital status, education, social class and occupation (Cohen et al , 1985 Bonaiuto et al , 1999 ; Pretty et al , 2003 ).

So far, several researchers have tried to measure it with varying definitions and dimensions of attachment to place. Schreyer and his colleagues with the classification attachment to the emotional and functional (Schreyer, 1981) And Giuliani and Feldman including researchers could be named with regard to various aspects of cognitive, emotional and behavior (Giuliani \& Feldman, 1993) about of them . William \& Vaske Research is the most important and most studies in this field that Design 15 statement in Likert type (William \& Vaske, 2003). Because its validity has repeatedly been confirmed in similar studies has been based this research. With this difference that in this study, the test has been addressed behavioral dimensions of place attachment, sense of achievement, that, as a committed and responsible behavior in relation to its place. For example has been proposed in different studies the behavioral dimension of attachment to place, to respect the rules and restrictions in place (Warzecha \& Lime, 2000), willingness to pay to maintain it (Kyle et al., 2003) and behaviors committed by Members (Vaske \& Korbin, 2001). So when will be full assess the interests individuals the place That in addition an evaluation of the location, should be evaluated both emotional and cognitive, behavioral and motivational effects on the individual (Chrkhchyan, 2010).

Therefore the existing literature in this field, define attachment to location the following four aspects that has been proposed statements based design and how to measure attachment to place:

- Emotional and feel with their own memories and his location in it.

- Function: to location the person depends on your needs and goes at it.

- Behavior: willingness to participate in and conduct held accountable in its location.

- Cognitive: distinctions physical features and location.

\section{Materials and Methods}

The literature review was conducted to measure user interest in the sample space, was designed a questionnaire comprising 15 statements in Likert type based on William U. study, First were put to the test with the participation of 50 civilians, Initial examination was changed the literature and how to the item described. Until most of the speech to establish a better relationship a Persian-speaking audience. It also reviewing the existing literature in this area, led to design of questionnaires, with a focus on four dimensions: functional, emotional, behavioral and cognitive in Table 1. In this study were interviewed a total of 598 persons, the users of Imam Street located in the city of Mahabad and was attempted various social groups to attend the random (Table 2). Independent variables in this study are including age, gender, education, marital status and occupation Volunteers that has been evaluation significant level on the dependent variable, users attached to the sample, and its four dimensions. The results of this research have been analyzed the software spss. And applying a different test, $\mathrm{t}$ - test and $\mathrm{F}$ - test.

Table 1 - tales of the research questions

\begin{tabular}{|c|l|}
\hline Dimension & \multicolumn{1}{|c|}{ statements } \\
\hline Functional & $\begin{array}{l}\text { Ilove places like Imam. } \\
\text { Another street does not prefer in Mahabad it. } \\
\text { Ilove my time in the streets. } \\
\text { The first is where I choose to get out of the house. }\end{array}$ \\
\hline The emotional & $\begin{array}{l}\text { When I am here, if Im at home } \\
\text { I have great memories of the Imam. } \\
\text { Imam Street is my favorite. } \\
\text { If possible be any day I came to the Imam. } \\
\text { People who are like me who went to the streets }\end{array}$ \\
\hline Behavioral & $\begin{array}{l}\text { - I am willing to keep those costs. } \\
- \text { Willing to keep doing what it is that I do. } \\
\text {-I feel people here are better behavior and more respectful manner. }\end{array}$ \\
\hline Cognitive & $\begin{array}{l}\text { - When I think of Mahabad The first place I recall Imam. } \\
\text { - Imam has all the qualities of a good street. } \\
- \text { What is the imam, has distinguished it, other than the streets of Mahabad. }\end{array}$ \\
\hline
\end{tabular}

Reference, Writers 
Imam Street, as a case study is one of the oldest streets in the city of Mahabad Which is located near the historic center of the city. The street now is as accumulation of space for residents, especially the youth, with various attractions: shopping, walking, leisure, and many of the key activities of the city, in terms of education, culture and health administration. This space has been selected the initial interview with the creation of citizens in different parts of the city, as the sample. At This stage was stationed the team consists of 5 people, 5 points the street and with the tenth person were conducted who has a desire to participate in research, personal interviews. Thus different sex and age groups participation have been that education levels and different jobs (Table 2).

Table 2 - Statistical characteristics of participants

\begin{tabular}{|c|c|c|c|c|c|}
\hline & Mean & $\begin{array}{c}\text { Standard } \\
\text { deviation }\end{array}$ & Minimum & Maximum & Total \\
\hline Age & 27.94 & 11.326 & 14 & 80 & 598 \\
\hline Marital status & .58 & .494 & - & - & 598 \\
\hline Sex & .51 & .500 & - & - & 598 \\
\hline Education & 12.70 & 3.030 & - & - & 598 \\
\hline & & & 0 & 20 & 598 \\
\hline
\end{tabular}

Reference, Writers calculations

II. CONCLUSIONS

In order to analyze the data were estimated the questionnaire Justifiability calculated with Crohn's alpha Bach, that was result obtained with the $0 / 83$, indicating the validity of the questionnaire designed to measure the dependent variable. After this step, in order to compare and analyze the results were calculated the average interest rate of separation of the different groups of participants that it will continue. It should be noted that due to statistical tables and analyzes were carried out only in the content is important consequences There are only a part of it.

In factor analysis user status the results suggests that the level of interest in all its aspects are different the two married and singles. Compare the differences, indicating that it is, however, a single users group have expressed more interested in the behavioral and cognitive aspects, only is seen slight difference both functional and emotional. Table 3 shows that despite the differences there is the only significant difference (significance $=$. /012) between the two groups in the behavioral dimension $(\mathrm{T}=2 / 510)$.

Table 3 - Results of t-test in the evaluate the relationship between marital status and level of attachment

\begin{tabular}{|c|c|c|c|c|c|c|c|c|}
\hline Dimension & $\mathrm{F}$ & $\mathrm{T}$ & $\mathrm{DF}$ & $\mathrm{sig}$ & $\begin{array}{c}\text { Mean } \\
\text { Difference }\end{array}$ & \multicolumn{2}{c|}{$\begin{array}{c}\text { Std. Error } \\
\text { Difference }\end{array}$} & \multicolumn{2}{|c|}{$\begin{array}{c}95 \% \text { Confidence Interval } \\
\text { of the Difference }\end{array}$} \\
\hline Functional & 1.673 & -.240 & 590 & .810 & -.4148 & .17261 & Lower & Upper \\
\cline { 7 - 9 } & & & & & & & .38049 & .29752 \\
\hline The emotional & .845 & - & 592 & .151 & -.2052 & .14287 & -.48586 & .7532 \\
\hline Behavioral & 1.691 & 2.510 & 590 & .012 & .4160 & .16575 & .9046 & .74153 \\
\hline Cognitive & .583 & 1.835 & 590 & .067 & .2956 & .16108 & .02073 & .61200 \\
\hline $\begin{array}{c}\text { attachment to } \\
\text { the place }\end{array}$ & 4.975 & .648 & 592 & .517 & .08696 & .13416 & .17652 & .35044 \\
\hline
\end{tabular}

Reference, Writers calculations

Next, was evaluated the relationship between gender and level of user Interest in all aspects of cognitive, emotional, and behavioral function through $\mathrm{t}$ - test. The result shows that although women have shown in reports are more Interest but is not observed significant correlation between gender and Interest, (see Table 4). In addition, analysis of variance ( $\mathrm{F}$ - test) was employed to evaluate users' job role include groups: self-employed, government, teachers, professors, engineers, retirees, students, workers, housewives. Comparison results show housewives, among other groups, have more Interest to the places studied, which result is also tangible in both functional and cognitive. But the emotional dimension, students have shown more Interest. But at this stage is achieved an interesting result that is significant relationship (significant =. /008) between workers and behavioral attachment to place (Table 5). 
Table 4 - Results of T-test to evaluate the relationship between marital status and level of attachment

\begin{tabular}{|c|c|c|c|c|c|c|c|c|}
\hline Dimension & $F$ & $\mathrm{~T}$ & DF & sig & $\begin{array}{c}\text { Mean } \\
\text { Difference }\end{array}$ & $\begin{array}{l}\text { Std. Error } \\
\text { Difference }\end{array}$ & \multicolumn{2}{|c|}{$\begin{array}{c}\text { Confidence Interval of the } \\
\text { Difference } 95 \%\end{array}$} \\
\hline & & & & & & & Lower & Upper \\
\hline Functional & 0.446 & $-1 / 306$ & 590 & $0 / 192$ & $-0 / 22196$ & $0 / 17001$ & $-0 / 55586$ & $0 / 11193$ \\
\hline The emotional & $0 / 886$ & $-0 / 253$ & 592 & 0,800 & $-0 / 03572$ & $0 / 14124$ & $-0 / 31311$ & $0 / 14167$ \\
\hline Behavioral & $0 / 243$ & $-1 / 017$ & 590 & $0 / 309$ & $0 / 16705$ & $0 / 16421$ & $0 / 48955$. & $0 / 15545$ \\
\hline Cognitive & $1 / 977$ & $1 / 533$ & 590 & $0 / 126$ & $0 / 24380$ & $0 / 15901$ & $-0 / 55609$ & $0 / 06850$ \\
\hline $\begin{array}{l}\text { attachment to } \\
\text { the place }\end{array}$ & $2 / 851$ & $1 / 262$ & 592 & $0 / 207$ & $0 / 16692$ & $0 / 13227$ & $-0 / 42671$ & $0 / 09286$ \\
\hline
\end{tabular}

Table 5 - Results of F-test - a test to evaluate the relationship between job and individual of attachment

\begin{tabular}{|c|c|c|c|c|c|}
\hline & Total & $\begin{array}{c}\text { Standard } \\
\text { deviation }\end{array}$ & median & F - Test & $\begin{array}{c}\text { Significance } \\
\text { level }\end{array}$ \\
\hline Functional & $66 / 513$ & $I I$ & $6 / 047$ & $1 / 423$ & $0 / 158$ \\
\hline The emotional & $45 / 139$ & $I I$ & $4 / / 20$ & $1 / 404$ & $0 / 167$ \\
\hline Behavioral & $100 / 832$ & $I I$ & $9 / 167$ & $2 / 355$ & $0 / 208$ \\
\hline Cognitive & $58 / 728$ & $I I$ & $5 / 339$ & $1 / 435$ & $0 / 153$ \\
\hline $\begin{array}{c}\text { attachment to } \\
\text { the place }\end{array}$ & $42 / 186$ & $I /$ & $3 / 835$ & $1 / 488$ & $0 / 131$ \\
\hline
\end{tabular}

In the last step was evaluated the relationship between two variables age and education, with variable attachment to the place, through Pearson correlation test (Table 6). As can be seen in Table 2 there is the only significant direct relationship between age and attachment to place its behavioral aspect.

It can be seen the variable education, and a significant indirect relationship between of attachment rates and education users. Moreover, is reduced with the increase in users education the emotional attachment to the sample space (significant $=$. /016).

Table 6 - Results of the correlation between the variables of education and age with attachment to place

\begin{tabular}{|c|l|c|c|c|c|c|}
\hline \multicolumn{2}{|c|}{} & Functional & $\begin{array}{l}\text { The } \\
\text { emotional }\end{array}$ & Behavioral & Cognitive & $\begin{array}{l}\text { attachment to the } \\
\text { place }\end{array}$ \\
\hline \multirow{2}{*}{ Age } & $\begin{array}{l}\text { Pearson } \\
\text { correlation }\end{array}$ & $-0 / 026$ & $-0 / 017$ & $0 / 135^{*}$ & $0 / 38$ & $0 / 25$ \\
\cline { 2 - 7 } & $\begin{array}{l}\text { Significance } \\
\text { level }\end{array}$ & $0 / 524$ & $0 / 671$ & $0 / 001$ & $0 / 360$ & $0 / 540$ \\
\hline Education & $\begin{array}{l}\text { Pearson } \\
\text { correlation }\end{array}$ & $-0 / 056$ & $-0 / 99^{*}$ & $-0 / 035$ & $-0 / 060$ & $-0 / 83^{*}$ \\
\cline { 2 - 7 } & $\begin{array}{l}\text { Significance } \\
\text { level }\end{array}$ & $0 / 176$ & $0 / 016$ & $0 / 401$ & $0 / 148$ & $0 / 043$ \\
\hline
\end{tabular}

\section{CONCLUSION}

As was mentioned in the literature review of demographic characteristics and their role in the of attachment to place, has been the subject of various studies. And so far, have been reported variables such as gender, age, income, marital status, social class, education and occupation as determinants in this regard (Cohen \& Shinar, 1983; Bonaiuto et al, 1999; Pretty, 2003). The study also tested the sample space. As a first result, comparison of the results of the analysis, reflecting the fact that are Single users, older people, women and labor groups, compared with the other groups, feel more of attachment to the case. As can be noted that the most significant finding in the study area has been education level users only determining factor in the amount of attachment them. Moreover despite some studies pointed the gender factor and its role in attachment to place, in the case study has not been observed such results, in conjunction with the attachment sites. This results is also true for users in variable marital status. Also although some studies have emphasized the jobs in this area, weren't found a significant relationship between this variable and attachment to place in the study. Meanwhile, variable of education has meaningful relationship with sense of attachment with this explanation has fallen the increased user education the rate of interest to a sample space It is also seen its emotional dimension.

\section{REFERENCES}

[1]. Ahrentzen, S. B. (1992) 'Home as a workplace in the lives of women', In I. Altman, and S. Low (Eds.), place attachment, New York: Plenum Press, 12,113-138.

[2]. Bonaiuto, M., Aiello, A., Perugini, M., Bonnes, M. and Ercolani, A.P. (1999) 'Multidimensional Environment quality and neighborhood attachment', Urban Environment, 19, 331-352. 
[3]. Bonaiuto, M., Fornara, F. and Bonnes, M. (2002) 'Indexes of perceived residential environment quality and neighborhood attachment in urban environments: a confirmation study on the city of Rome', Landscape and Urban Planning, 988, 1-12.

[4]. Charkhchyan. Maryam (2010), Analytical study of factors affecting the interests of urban public spaces, Architecture PhD Thesis, Faculty Architecture, University of Science and Technology

[5]. Cohen, Y.S. and Shinar, A. (1985) Neighborhoods and Friendship Networks, Chicago, the University of Chicago.

[6]. Daneshpour. S (2010) model of attachment to place and explain the various different aspects, Fine Art Magazine, Issue 38. Tehran University.

[7]. Eisenhauer, B.W., Krannich, R.S. and Blahna, D.J. (2000) 'Attachments to special places on public lands: An analysis of activities, reason for attachments, and community connections', Society and Natural Resources, 13, 421-441.

[8]. Ellaway, A., and Macintyre, S. (1996) 'Does where you live predict health related behaviours? A case study in Glasgow', Health Bulletin, 54, 443-446.

[9]. Giuliani, M.V. and Feldman, R. (1993) 'Place attachment in a developmental and cultural context', Journal of Environmental Psychology, 13, 267-274.

[10]. Hidalgo, M.C., and Hernandez, B. (2001) 'Place attachment: Conceptual and empirical questions', Journal of Environmental Psychology, 21, 273-281.

[11]. Johnson, C.Y. 91998) 'A consideration of collective memory in African American attachment to wildland recreation places', Human Ecology Review. 5, 5-15.

[12]. Kyle, G.T., Absher, J.D. and Graefe, A.R. (2003) 'The moderating role of place attachment on the relationship between attitude toward fees and spending preferences', Leisure Sciences, 25, 33-50.

[13]. Low, S.M., and Altman, I. (1992) 'Place attachment: a conceptual inquiry', In Low, S.M. and Altman, I. (Eds.) Place Attachment, New York, Plenum Press, 12, 1-12.

[14]. Low, S.M. and McDonogh, G.W. (2001) 'Remapping the city: Place, Order and Ideology', American Anthropologist, 103:1, 5-6

[15]. Moore, R.L. and Graefe, A.R. (1994) 'Attachments to recreation settings: The case of rail-trail users', Leisure Sciences, 16, 17-31.

[16]. Oswald, F., and Wahl, H.W. (2001) 'Housing in old age: conceptual remarks and empirical data on place attachment', IAPS Bulletin of People-Environment Studies, 19, 7-11.

[17]. Pretty, G., Chipuer, H.M., Bramston, P. (2003) 'Sense of place among adolescence and adults in two rural Australian towns: The discriminating features of place attachment, sense of community and place dependence in relation to place identity', Journal of Environmental Psychology, 23, 273-287.

[18]. Proshansky, H.M., Fabian, A.K. and Kaminoff, R. (1983) 'Place-identity: physical world socialization of the self', Journal of Environmental Psychology, 3, 57-83.

[19]. Riley, R. (1992) 'Attachment to the Ordinary Landscape' In I. Altman and S. M. Low (Eds.), Place Attachment, New York, Plenum Press.

[20]. Rohe, W.M. and Stegman, M.A. (1994) 'The impact of home ownership on the social and political involvement of low-income people', Urban Affairs, 30:1, 152-172.

[21]. Rubinstein, R.L and Parmelee, P.A. (1992) 'Attachment to place and representation of the life course by the elderly', In I. Altman and S. M. Low (Eds.), Place Attachment, New York, Plenum Press.

[22]. Schreyer, R., Jacob, G., and White, R. (1981) 'Environmental meaning as a determinant of spatial behavior in recreation', In J. Frazier and B. Epstein (Eds.), Proceedings of the Applied Geography Conferences. Binghamton, Dept. of Geography, SUNY Binghamton, 294-300.

[23]. Stedman, R. C. (2003) 'Is it really just a social construction? The contribution of the physical environment to sense of place'. Society and Natural Resources, 16:8, 671-685.

[24]. Tuan, Y.F. (1977) Space and place: The perspective of experience, Minneapolis, University of Minnesota Press.

[25]. Vaske, J.J., and Kobrin, K.C. (2001) 'Place attachment and environmentally responsible behavior', The Journal of Environmental Education, 32:4, 16-21.

[26]. Warzecha, C. A., and Lime, D.W. (2001) 'Place attachment in Canyon lands National Park: Visitors' assessment of setting attributes on the Colorado and Green Rivers', Journal of Park and Recreation Administration, 19:1, 59-78.

[27]. Williams, D.R., Patterson, M.E., Roggenbuck, J.W., and Watson, A. E. (1992) 'Beyond the commodity metaphor: Examining emotional and symbolic attachment to place', Leisure Sciences, 14, 29-46.

[28]. Williams, D.R., and Vaske, J.J. (2003) 'the measurement of place attachment: Validity and generalizability of a psychometric approach', Forest Science, 49:6, 830-840. 